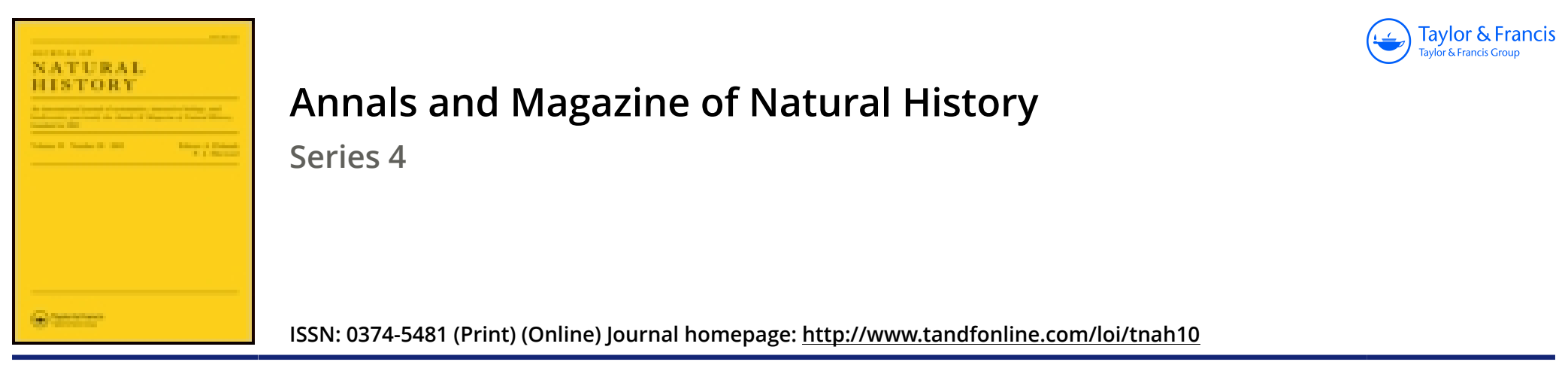

\title{
On the mode of development of Bothriocephalus latus
}

\section{Knoch}

To cite this article: M. Knoch (1869) On the mode of development of Bothriocephalus latus, Annals and Magazine of Natural History, 3:15, 243-243, DOI: $10.1080 / 00222936908695925$

To link to this article: http://dx.doi.org/10.1080/00222936908695925

Published online: 16 Oct 2009.

Submit your article to this journal \lceil

Џ Article views: 4

Q View related articles $\longleftarrow$ 
elongated well-developed dorsal spot of a pure white. It differs from all the other species of the restricted genus in the length and narrowness of the nose of the skull. I have called the species Hyrax Bocagei.

On the mode of Development of Bothriocephalus latus.

By M. KNocr.

According to a report by M. C. Robin, presented to the Academy of Sciences in Paris, M. Inoch has porfectly demonstrated that the embryo of Bothriocephalus latus passes through no cysticercal stage in the course of its development.--Comptes Rendus, January 11, 1869, p. 90 .

Teeth of Streptaxis, Chilina, \&e.

Dr. F. D. Heynemann, in the 'Nalak. Blätter' for 1868, has described and figured the teeth of different terrestrial Mollusca, as, for example, the genera Streptaris, Pellicule, Simulopsis, and Chilina. The teeth of Streptaxis are fusiform, with a more or less distinct rounded lobe on the front of each side near the base, somewhat like the teeth of Testacella and other worm-eating slugs; I had some timo ago predicted that the tecth would be of that form, from the earnivorous habits of the genus. The Brazilian collectors of shells know that these snails will eat the animals out of the shells of the Helices that are shut up in a box with them. The animal of Chilina has a strong lunate jaw with a grooved front surface and a crenated lower edge; and the onter lateral teeth are large and pectinated on their upper edge. The teeth of the other genera are like those of the other herbivorous Helicidæ.-J. E. Gray.

\section{Naultinus lineatus, a New Lizard from New Zealand. By Dr. J. E. Grax, F.R.S.}

Mr. W. Adams has just returned from New Zealand and brought with him a new species of Naultinus, which I propose to call N. 7 neatus, as it differs from the other species in having three yellow dorsal streaks-one central, and the others on the outer part of the sides of the back. The lateral streals are well marked in all the three specimens, which are of different ages; the central dorsal streak is indistinct in the two young, but more distinct and well marked in the adult, which is said to be a female and mother of the other two. They were procured at Otraroa, the French settlement in Canterbury, New Zealand.

\section{Marine Animals of Southern Labrador.}

Dr. O.S. Packman, jun., has published a list of marine animals dredged, during a fifty days' visit, near Caribou Island, Southern Labrador, in the Gulf of St. Lawrence, in which several new species are described, with most interesting observations on the distribution of the more common species,-interesting as they seem to afford very satisfactory evidence that there are three distinct assemblages of marine invertebrates intermingled on the coast of Northern Labrador. 